\title{
Concentration of Heavy Metals and Health Risk Assessment of Consumption of Fish (Sarotherodon melanotheron) from an Estuarine Creek in the Niger Delta, Nigeria
}

\author{
M. Moslen* and C. A. Miebaka \\ Department of Applied and Environmental Biology, Rivers State University of Science and Technology, Port \\ Harcourt, Nigeria. \\ Institute of pollution Studies, Rivers State University of Science and Technology, Port Harcourt, Nigeria.
}

\begin{abstract}
Health risk assessment with respect to heavy metals concentration and consumption of fish (Sarotherodon melanotheron) obtained from Azuabie creek was carried out. Five fish samples composited were obtained from fishermen on a monthly basis from January - December 2015. Heavy metals ( $\mathrm{Cr}, \mathrm{Ni}, \mathrm{Cu}, \mathrm{Pb}, \mathrm{Ag}$ and $\mathrm{Cd}$ ) analysis was done using Atomic Absorption Spectrophotometery while health risk to consumers was evaluated using Estimated Daily Intake, Target Harzard Quotient, Hazard Index and Target Cancer Risk. Metal concentration in fish tissue were $\mathrm{Cu}>\mathrm{Pb}>\mathrm{Cr}>\mathrm{Ni}>\mathrm{Ag}>\mathrm{Cd}$ with the following mean values $5.59 \pm 1.06$ $m \mathrm{mkg}^{-1}, 5.12 \pm 1.23 \mathrm{mgkg}^{-1}, 2.69 \pm 1.44 \mathrm{mgkg}^{-1}, 1.94 \pm 0.34 \mathrm{mgkg}^{-1}, 1.02 \pm 0.34 \mathrm{mgkg}^{-1}$ and $0.38 \pm 0.08 \mathrm{mgkg}^{-1}$ respectively. $\mathrm{Ni}, \mathrm{Pb}$ and $\mathrm{Cd}$ had mean values above recommended FAO/WHO limits. EDI values (mgkg ${ }^{-1}$ bw/day) were $\mathrm{Cu} 0.93 \times 10^{-3}, \mathrm{~Pb} 0.85 \times 10^{-3}, \mathrm{Cr} 0.45 \times 10^{-3}, \mathrm{Ni} 0.32 \times 10^{-3}, \mathrm{Ag} 0.17 \times 10^{-3}$ and $\mathrm{Cd} 0.063 \times 10^{-3}$. $T H Q$ values were as follows: $\mathrm{Cr} \mathrm{O.29,} \mathrm{Pb} \mathrm{0.24,Cd} \mathrm{0.06,Cu} 0.023$ and $\mathrm{Ni} 0.016$ while the HI for all metals had a value of 0.64 and the TR for Ni had a value of $2.63 \times 10^{-3} \mathrm{mgkg}^{-1} \mathrm{bw}$-day ${ }^{-1}$. The study concluded that fish muscle obtained from the study area showed bio-accumulation of metals over time but health risk assessment indices indicated minimal to moderate risk levels suggesting insignificant health risk. This could douse public health concerns in terms of human exposure via consumption of fish but regular monitoring is advised to detect changes in metal concentration.
\end{abstract}

Keyword: Azuabie creek, Fish, Heavy metals, Health Risk, Niger Delta

\section{Introduction}

Increase in population has induced urbanization and industrialization with corresponding discharge of wastes such as heavy metals into the environment. Heavy metals occur naturally in aquatic ecosystem, but deposits of anthropogenic origin increase their levels and create environmental problems in coastal zones and rivers [1]. Such metals have been described as non-biodegradable and persistent in the environment and known to cause deleterious effects on animal and human health $[2,3,4]$. Heavy metal pollution is one of the challenges of coastal water pollution as a result of human activities such as oil exploration and exploitation, construction and fabrication of marine boats, disposal of industrial and domestic wastes and sailing [5]. It has also been reported that heavy metals are significant environmental pollutants and their toxicity is a problem of increasing significance for ecological, evolutionary, nutritional and environmental reasons [6, 7]. Fishes are sensitive indicators of heavy metals pollution [8]. Fish from natural aquatic environment are consumed everyday for nutritional requirements and this could expose such consumers of fish from presumed polluted areas to health risks. [9] and [10] had stated that dietary intake of toxic elements is the main route of exposure for most people. Excess amounts of these metals entering into the aquatic ecosystem may pollute the environment and also affect the food chain and ultimately pose serious human health risks to those who depend directly or indirectly on the water body for the supply of fish and water [11]. [12] also found that fish raised in contaminated waters take up heavy metals in large quantities enough to cause potential health risks to the consumers. [13] then stated that analysis of fish muscle helps to determine the direct transfer of heavy metals and other contaminants to humans via fish consumption. Data on health risk assessment with regards to heavy metal level and consumption of Sarotherodon melanotheron obtained in the study area was scarce. This study therefore, aimed to examine the concentrations of some heavy metals $(\mathrm{Cr}, \mathrm{Ni}, \mathrm{Cu}, \mathrm{Pb}, \mathrm{Ag}$ and $\mathrm{Cd})$ and health risks exposure to consumers of Sarotherodon melanotheron obtained from a presumed polluted creek (Azuabie) in the upper Bonny estuary of the Niger Delta, Nigeria. 


\section{Materials And Methods}

All fish samples were collected from the Azuabie creek in the Niger Delta, Nigeria (Fig. 1). The method of collection was by cast net via fishermen on the creek. Five samples of fish (Sarotherodon melanotheron) were collected and made composite samples every month for twelve months (January December 2015). The composited samples were dried and digested using $\mathrm{HCl} / \mathrm{HNO}_{3}$ following the method of the American Society for Testing and Materials [14](ASTM, 1986). The heavy metals concentration was assessed using an Atomic Absorption Spectrophotometer (GB Avanta PM AAS, S/N A6600). The concentrations were blank-corrected and expressed as $\mathrm{mgkg}^{-1}$ dry weight of sample.

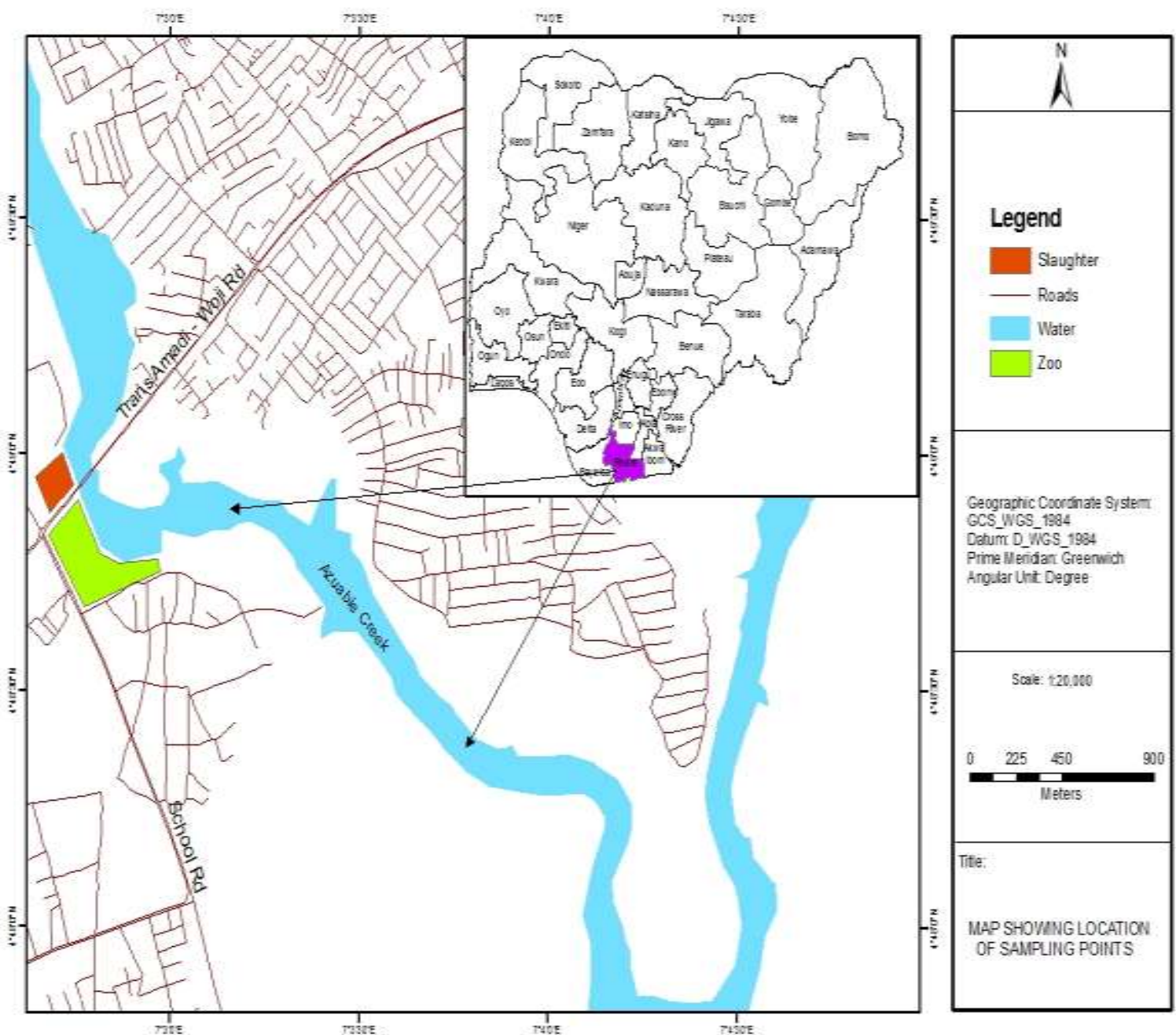

Fig. 1: Location of Study site.

Estimated daily intake (EDI): Studies have shown that ingestion of contaminated food is exposure pathway of heavy metals to human $[12,15]$. Estimated daily intake (EDI) of heavy metals examined in this study determined using the equation:

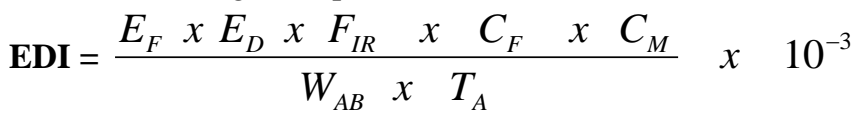

$\mathrm{E}_{\mathrm{F}}=\quad$ Exposure frequency, 365 days/year

$E_{D}=$ Exposure duration, equivalent to verge life time (65 years)

$F_{I R}=\quad$ Fresh food ingestion rate ( $\mathrm{g} /$ person/day) which was considered to be $48 / \mathrm{g} /$ person/day [16]

$\mathrm{C}_{\mathrm{F}}=\quad$ Conversion factor $=0.208$

$\mathrm{C}_{\mathrm{M}}=$ Heavy metal concentration in food stuffs ( $\mathrm{mgkg}^{-1}$ dry-weight $)$

$\mathrm{W}_{\mathrm{AB}}=$ Average body weight (bw) was taken as $60 \mathrm{~kg}$ )

$T_{A}=\quad\left(E_{F} \times E_{D}\right)$ Is the average exposure of time for non-carcinogens as used by previous studies [17]. The public health risk was evaluated using the EDI [18] to determine the Target Hazard Quotient (THQ). 
Target hazard quotient $(\mathrm{THQ})$ is given by: $\mathbf{T H Q}=\frac{E D I}{R F D O}$

Where EDI $=$ Estimated daily intake

$\mathrm{RFDO}=$ the reference oral dose of individual metal $\left(\mathrm{mgkg}^{-1} \mathrm{day}^{-1}\right)$.

Reference oral doses (RfD) used for $\mathrm{Cr}, \mathrm{Cu}, \mathrm{Ni}, \mathrm{Pb}$, and $\mathrm{Cd}$ are $1.5 \times 10^{-3}, 4.0 \times 10^{-2}, 2.0 \times 10^{-2}, 3.5 \times 10^{-3}, 1.4 \mathrm{x}$ $10^{-1}$ and $1.0 \times 10^{-3} \mathrm{mgkg}^{-1}$ day $^{-1}$ respectively [19].

Hazardous index (HI): Estimation of the risk of more than one heavy metal to human health, the hazard index (HI) was developed [20] which is the sum of the hazard quotients for all metals and calculated by the equation [21].

$\mathrm{HI}=\sum \mathrm{HQ}=\mathrm{HQ}_{\mathrm{cr}}+\mathrm{HQ}_{\mathrm{Cu}}+\mathrm{HQ}_{\mathrm{Ni}}+\mathrm{HQ}_{\mathrm{pb}}+\mathrm{HQ}_{\mathrm{cd}}$

Target Cancer Risk (TR): The Target cancer risk (TR) was evaluated based on USEPA (2011) using the formula

\section{$\mathrm{TR}=\underline{\mathrm{Mc} \times \mathrm{IR} \times 10^{-3} \times \mathrm{CPSo} \times \mathrm{EF} \times \mathrm{ED}}$}

BW $\times$ ATc

where $\mathrm{MC}=$ metal concentration, $\mathrm{IR}=$ ingestion rate, $\mathrm{EF}=$ exposure frequency, $\mathrm{ED}=$ Exposure duration, $\mathrm{BW}$ $=$ Body weight, $\mathrm{CPSo}=$ carcinogenic potency slope, oral $\left(\mathrm{mgkg}^{-1} \mathrm{bw}-\mathrm{day}^{-1}\right.$ which is $1.7 \mathrm{for} \mathrm{Ni}-[22,23]$. ATc is the averaging time for carcinogens ( 365 days/year $\times 67$ years)

\section{Results}

Temporal variation in the distribution of heavy metals in fish tissue (muscle) was obvious but of no particular trend (Figs. 2 - 7) even though, values seemed to be higher during the dry season months of November and December. In order of increasing metal concentrations, $\mathrm{Cu}>\mathrm{Pb}>\mathrm{Cr}>\mathrm{Ni}>\mathrm{Ag}>\mathrm{Cd}$ with the following mean values $5.59 \pm 1.06 \mathrm{mgkg}^{-1}, 5.12 \pm 1.23 \mathrm{mgkg}^{-1}, 2.69 \pm 1.44 \mathrm{mgkg}^{-1}, 1.94 \pm 0.34 \mathrm{mgkg}^{-1}, 1.02 \pm$ $0.34 \mathrm{mgkg}^{-1}$ and $0.38 \pm 0.08 \mathrm{mgkg}^{-1}$ respectively (Table 1). The concentrations of $\mathrm{Ni}, \mathrm{Pb}$ and $\mathrm{Cd}$ were above their respective $\mathrm{FAO} / \mathrm{WHO}$ recommended limits while $\mathrm{Cu}$ and $\mathrm{Cr}$ had values below. The values of the estimated daily intake $\left(\mathrm{mgkg}^{-1}\right.$ body weight day $\left.{ }^{-1}\right)$ for the metals were $\mathrm{Cu} 0.93 \times 10^{-3}, \mathrm{~Pb} 0.85 \times 10^{-3}, \mathrm{Cr} 0.45 \times 10^{-3}, \mathrm{Ni}$ $0.32 \times 10^{-3}, \mathrm{Ag} 0.17 \times 10^{-3}$ and $\mathrm{Cd} 0.063 \times 10^{-3}$. Target hazard quotient was evaluated to determine potential health risk to consumers of fish and the values were as follows: $\mathrm{Cr} 0.29, \mathrm{~Pb} \mathrm{0.24}, \mathrm{Cd} 0.06, \mathrm{Cu} 0.023$ and $\mathrm{Ni}$ 0.016 while the Hazard index (HI) was done in view of the interactive and synergistic effect of more than one heavy metal in tissues. The HI value for all metals in this study had a value of 0.64 while the Target cancer risk (TR) was determined for Ni only and had a value of $2.63 \times 10^{-3}$. Only the CPSo of Ni was available.

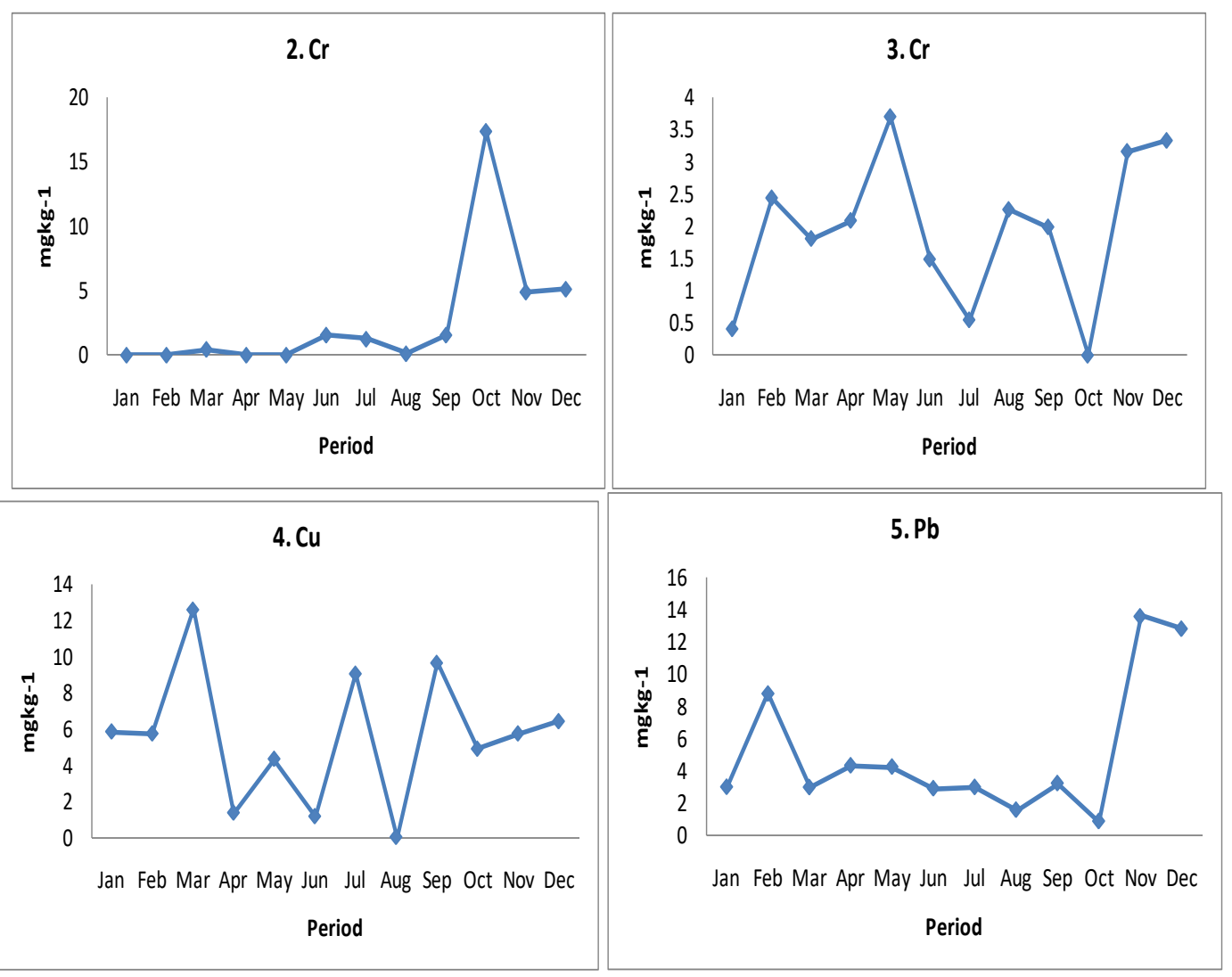




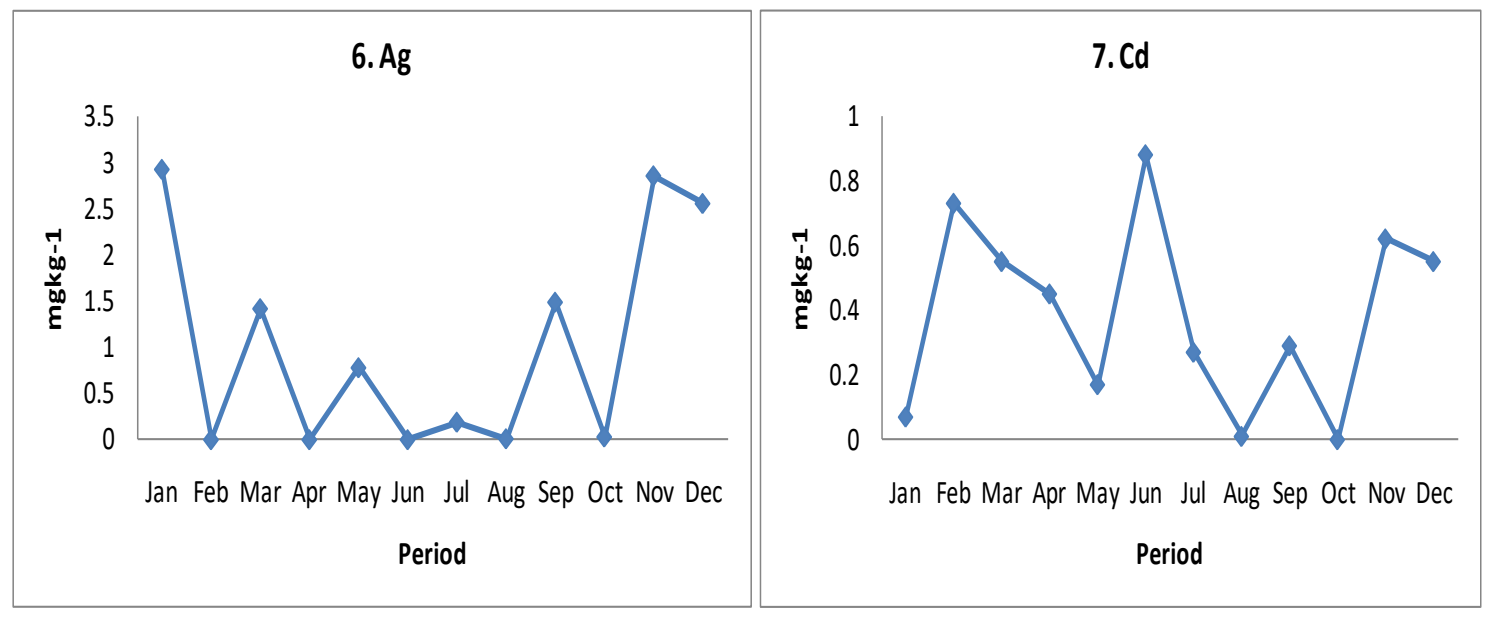

Figs. 2 -7: Temporal fluctuation of heavy metal concentration fish tissue (Muscles)

Table 1: Mean Concentration of Heavy Metals in Fish tissue (Muscle) and Recommended Limits

\begin{tabular}{|l|l|l|}
\hline Heavy Metals & Concentration in fish Muscle & Recommended limits (ppm) \\
\hline $\mathrm{Cr}\left(\mathrm{mgkg}^{-1}\right)$ & $2.69 \pm 1.44$ & $12-13[24,25]$ \\
\hline $\mathrm{Ni}\left(\mathrm{mgkg}^{-1}\right)$ & $1.94 \pm 0.34$ & $0.2[26]$ \\
\hline $\mathrm{Cu}\left(\mathrm{mgkg}^{-1}\right)$ & $5.59 \pm 1.06$ & $30[27]$ \\
\hline $\mathrm{Pb}\left(\mathrm{mgkg}^{-1}\right)$ & $5.12 \pm 1.23$ & $0.5[28]$ \\
\hline $\mathrm{Ag}\left(\mathrm{mgkg}^{-1}\right)$ & $1.02 \pm 0.34$ & No guideline \\
\hline $\mathrm{Cd}\left(\mathrm{mgkg}^{-1}\right)$ & $0.38 \pm 0.08$ & $0.1[29]$ \\
\hline
\end{tabular}

Table 2: Values of EDI, THQ, HI and TR of the Heavy Metals Examined

\begin{tabular}{|c|c|c|c|c|}
\hline Heavy Metals & EDI & THQ & $\mathrm{HI}$ & TR \\
\hline $\mathrm{Cr}$ & $0.45 \times 10^{-3}$ & 0.298 & \multirow[b]{6}{*}{0.64} & \\
\hline $\mathrm{Ni}$ & $0.32 \times 10^{-3}$ & 0.016 & & $2.63 \times 10^{-3}$ \\
\hline $\mathrm{Cu}$ & $0.93 \times 10^{-3}$ & 0.023 & & \\
\hline $\mathrm{Pb}$ & $0.85 \times 10^{-3}$ & 0.024 & & \\
\hline $\mathrm{Ag}$ & $0.17 \times 10^{-3}$ & & & \\
\hline $\mathrm{Cd}$ & $0.063 \times 10^{-3}$ & 0.063 & & \\
\hline
\end{tabular}

\section{Discussion}

Fish muscle tissue was examined in this study because it is the most consumed part of the fish but it has been reported to be inactive in accumulating heavy metals [30]. The concentration of heavy metals observed in this study is comparable to the range reported in fish (mudskipper) muscle tissues [5] but generally higher compared to values recorded in different fish species from the study area [31]. The implication of this is gradual accumulation of heavy metal in biota of the Azuabie creek which is attributable to anthropogenic activities in the study area including the discharge of domestic, industrial and municipal wastes into the creek [32, 33, 34, 35 , 5]. The levels of $\mathrm{Pb}, \mathrm{Cd}$ and $\mathrm{Ni}$ observed in this study also exceeded the recommended maximum permissible limits [28] and [36]. These concentrations may pose contamination concern for consumers of such fish from the Azuabie area. The level of $\mathrm{Pb}$ observed in this study is however, within the range recorded elsewhere [37, 12] but generally higher than values obtained by [38] while those of $\mathrm{Cu}$ found in the current study compared well with the range (3.01 - $\left.17.47 \mathrm{mgkg}^{-1}\right)$ observed in fish tissue in Gaza stripe [38] and could be considered as concentrations found in uncontaminated fish During feeding fish ingest contaminants indiscriminately including heavy metals which build up gradually along the food chain with subsequent exposure of humans who consume such fish. Since intake of fish is a possible source of accumulation of metals [38] stated that there is an important need in calculating the daily and weekly consumptions of heavy metals through fish eating. Health risk assessment in view of human exposure to heavy metals via consumption of fish from Azuabie creek was done for this study with the EDI values of the metals generally less than their respective oral reference doses (RFD) suggesting minimal risk of human exposure. The EDI values obtained in this study were generally less compared to the findings of [39] who worked on Scomber scombrus in Zaria Nigeria. They reported daily intake of metal (DIM) for three categories of individuals as Cd $1.162 \times 10^{-3}, 1.482$ $\times 10^{-3}$, and $2.633 \times 10^{-3} \mathrm{mg} \cdot \mathrm{kg}^{-1}, \mathrm{~Pb} 5.833 \times 10^{-3}, 7.559 \times 10^{-3}$, and $1.289 \times 10^{-2} \mathrm{mg} \cdot \mathrm{kg}^{-1}$ and Ni $3.906 \times 10^{-3}$, $4.861 \times 10^{-3}$, and $8.636 \times 10^{-3}$. EDI values obtained in this study however, compared favourably with values reported by [13] within the West African region and those found by [40] around the Persian Gulf. [13] Stated that RfD represents an estimation of the daily exposure of a contaminant to which the human population may be continually exposed over a lifetime without an appreciable risk of harmful effects. Values of $\mathrm{Pb}, \mathrm{Cd}$ and $\mathrm{Ni}$ in 
this study were above recommended limits of the FAO/WHO but may not pose human health risk in view of the fact that their EDI values were less than their respective RFD values but regular monitoring is necessary to detect increases in metal accumulation. [41] found that values of estimated daily intakes (EDI) of $\mathrm{Zn}, \mathrm{Cd}, \mathrm{Pb}$ and $\mathrm{Ni}$ in muscles of fish in their study were well below their corresponding permissible tolerable daily intake and concluded that fish were safe for human consumption. The Target hazard quotient (THQ) for the metals in the current study showed that $\mathrm{Cr}>\mathrm{Pb}>\mathrm{Cd}>\mathrm{Cu}>\mathrm{Ni}$ with all the values $<1$ suggesting minimal risk of non carcinogenic consequence but $\mathrm{Cr}$ showed higher potential health risk than other metals. THQ > 1 has been said to indicate potentials of non carcinogenic risk to human exposures [42, 43, 44] particularly with increase in metal exposure. The THQ of metals in this study $(<1)$ agrees with the findings of [45] and [46] but disagreed with the findings of [47] who reported $>1 \mathrm{THQ}$ for $\mathrm{Pb}, \mathrm{Cr}$, and $\mathrm{Hg}$ in fish from the coast of India. The Hazard index (HI) of all the metals was also calculated in view of the fact that more than one metal can often be bioaccumulated in fish tissue as observed in this study. Such metals could have interactive or synergistic effects. The HI value (0.64) observed in this study was also < 1suggesting minimal risk exposure of no significant health risk to consumers of Sarotherodon melanotheron obtained from the study area. Studies have reported that HI should not be $>1$ in order to ease public health concern $[48,49]$. The HI of this study agrees with the findings of [40] who also reported values of $<1$. The percentage contribution of each heavy metal in the hazard index as thus: $\mathrm{Cr}(46.4 \%), \mathrm{Pb}(37.8 \%), \mathrm{Cd}(9.8 \%), \mathrm{Cu}(3.6 \%)$ and $\mathrm{Ni}(2.5 \%)$. The target carcinogenic risk (TR) was calculated for only Ni whose CPSo (carcinogenic potency slope, oral $\left(\mathrm{mg} / \mathrm{kg} \mathrm{bw}-\mathrm{day}^{-1}\right)$ was available and the value obtained was $2.63 \times 10^{-3}$. This value indicates a moderate condition compared to the range issued by [50]. This value is not absolute but gives an upper limit likelihood that an exposed person may have cancer once in life [50].

\section{Conclusion}

The study therefore concluded that heavy metal bioaccumulation over time is imminent in biota particularly fish obtained from Azuabie creek looking at studies carried out in the area. The health risk assessment indices (EDI, THQ, HI and TR) evaluated for this study showed minimal to moderate risk levels with respect to human exposure vis-à-vis consumption of Sarotherodon melanotheron from the study area. This may minimize public health concerns but regular monitoring is strongly recommended.

\section{Acknowledgement}

The authors appreciate the contribution of G. ogbe for map production and cooperation of Anal Concept during laboratory analysis. This research was self funded by the authors.

\section{References}

[1]. M. Dural, M.Z.L. Goksu and A.A. Ozak,. Investigation of heavy metal levels in economically important fish species captured from the Tuzla Lagoon, 102, 2007, 415-421.

[2]. S. Davydova, Heavy metals as toxicants in big cities, Microchem J 79, 2005, 133-136.

[3]. M. Javed, and N. Usmani, Accumulation of heavy metals in fishes: a human health concern. Int J Environ Sci 2, 2011, 659-670.

[4]. M. Javed, and N. Usmani, Toxic effects of heavy metals $(\mathrm{Cu}, \mathrm{Ni}, \mathrm{Fe} \mathrm{Co}, \mathrm{Mn}, \mathrm{Cr}, \mathrm{Zn})$ to the haematology of Mastacembelus armatus thriving in Harduaganj Reservoir, Aligarh, India. Global J Med Res, 2012, 12:59-64.

[5]. M. Moslen, and C.A. Miebaka, Temporal Variation of Heavy Metal Concentrations in sp obtained from Azuabie Creek in the Upper Bonny Estuary, Nigeria, Current Studies in Comparative Education, Science and technology, Vol 3(2) 2016,136-147.

[6]. M. Jaishankar, T. Tseten, N. Anbalagan, B.B. Mathew, and K.N. Beeregowda, Toxicity, mechanism and health effects of some heavy metals. Interdiscip Toxicol 7(2), 2014, 60-72.

[7]. P.C. Nagajyoti, K.D. Lee, and T.V.M Sreekanth, Heavy metals, occurrence and toxicity for plants: a review. Environ Chem Lett; 8(3), 2010,199-216.

[8]. O.G. Adeyemi, G.O. Adediran, and T. Oyeniyi, Some trace elements concentration in a variety of fishes from Asa River, Ilorin, Nigeria. Bioscience Research Communications 8 (2), 1996, 99-102.

[9]. J. Calderon, D. Ortiz-Perez, L. Yanez, and F. Diaz-Barriga, Human exposure to metals. Pathways of exposure, biomarkers of effect, and host factors. Ecotoxicol Environ Saf 56, 2003, 93-103.

[10]. K.M. Powers, T. Smith-Weller, G.M. Franklin, W.T. Longstreth, P.D. Swanson, and H. Checkoway, Parkinson's disease risks associated with dietary iron, manganese, and other nutrient intakes. Neurology 60, 2003, 1761-1766.

[11]. Y. Weldegebriel, B.S, Chandravanshi, and T. Wondimu, Concentration levels of metals in vegetables grown in soils irrigated with river water in Addis Abada, Ethiopia. Ecotoxicology and Environmental Safety, 77, 2012, 57-63.

[12]. C. Copat, F. Bella, M. Castaing, R. Fallico, S Sciacca, and M. Ferrante, Heavy metals concentrations in fish from Sicily (Mediterranean Sea) and evaluation of possible health risks to consumers. Bulletin of Environmental Contamination and Toxicology, 88, 2012, 78-83

[13]. O. Akoto, E.F. Bismark, G. Darko, and E. Adei, Concentrations and Health Risk Assessments of Heavy Metals in Fish from the Fosu Lagoon. Int. J. Environ. Res., 8(2), 2014, 403-410.

[14]. American Society for Testing and Materials ASTM Annual book of ASTM standards, 11.01, D3559-85, Philadelphia PA 19103, 1986.

[15]. N.S. Chary, C.T. Kamala, and D.S. RajAssessing risk of heavy metals from consuming food grown on sewage irrigated soil and food chain transfer, Ecotoxicology and Environmental Safety, 69, 2008, 513-524.

[16]. M. Ali, and V.T.B Hau, Vegetables in Bangladesh Economic and nutritional impact of new varieties and technologies. Asian Vegetable Research and Development Centre, Technical Bulletin No. 25, 2001, AVRDC, Taiwan. 
[17]. X. Wang, T. Sato, B. Xing, and S Tao. Health risk of heavy metals to the general public in Tianjin, China via Consumption of vegetables and fish, Science Total Environment, 350, 2005, 28-37.

[18]. L.C. Chien, L. Hung, K.Y. Choang, C.Y. Yeh, P.J. Meng, M.J. Shieh, and B.C. Han, $\quad$ Daily intake of TBT, Cu, Zn, Cd and As for fisherman in Taiwan, The Science of the Total Environment, 285, 2002, 177-185.

[19]. USEPA, United States Environmental Protection Agency, Risk-based concentration table. Philadelphia: United States Environmental Protection Agency, Washington, DC, 2009.

[20]. USEPA Risk assessment Guidance for Superfund. Human Health Evaluation Manual Part A, interim final, vol. 1. Washington (DC) 7 United States Environmental Protection Agency; EPA/540/1-89/002, 1989.

[21]. K. Guerra, J. Konz, K. Lisi, and C. Neebrem, Exposure Factors handbook. USEPA, Washington D.C, 2010.

[22]. USEPA (United States Environmental Protection Agency), USEPA Regional Screening Level (RSL) Summary Table: November 2011. Available at: http://www.epa.gov/regshwmd/risk/human/Index.htm, last update: 20th January, 2014.

[23]. USEPA (United States Environmental Protection Agency) EPA Region III Risk-Based Concentration (RBC) Table 2008 Region III, 1650 Arch Street, Philadelphia, Pennsylvania 19103, 2012.

[24]. USFDA Food and drug administration, Guidance document for nickel in shell fish. DHHS/PHS/FDA/CFSAN/office of seafood, Washington, DC, 1993.

[25]. M.S. Rahman, A.H. Molla, N. Saha, A. Rahman, Study on heavy metals levels and its risk assessment in some edible fishes from Bangshi River, Savar, Dhaka, Bangladesh, Food Chem, 134(4), 2012, 1847-54.

[26]. WHO, "Background document for development of WHO guidelines for nickel in drinking-water quality and fish," Tech. Rep. WHO/Sde/Wsh/05.08/55, 2005.

[27]. FAO, WHO Compilation of legal limits for hazardous substances in fish and fishery products, Fish Circular, 464, 1983, 5-100.

[28]. FAO/WHO Evaluation of certain food additives and the contaminants mercury, lead and cadmium; WHO Technical Report Series No. $505,1989$.

[29]. FAO, Heavy Metals Regulations: Part 1. Legal Notice no. 66, http://www.faolex.fao.org/docs/pdf/eri42405.pdf. 2003.

[30]. M.B ahnasawy, A. Khidr, and N. Dheina, Seasonal variations of heavy metals concentrations in Mullet, Mugil cephalus and Liza ramada (Mugilidae) from Lake Manzala, Egypt. J. Appl. Sci. Res. 5, 2009, 845-852.

[31]. E.R. Daka, C.A. Ekeh, and M. Moslen, Cadmium and lead level in some fish species from Azuabie creek in the Bonny Estuary, Nigeria. African J. Biotech., 7, 2008, 63-64.

[32]. M. Moslen, E.R. Daka, C.A. Ekeh, and I.K.E. Ekweozor, Physicochemical properties of two estuarine creeks in the Niger Delta in relation to urban/industrial activities, Niger Delta Biologia, 5(2), 2006,115-122.

[33]. E.R. Daka, M. Moslen, C.A. Ekeh and I.K.E. Ekweozor, Sediment quality status of two creeks in the upper Bonny estuary, Niger Delta, in relation to urban/industrial activities. Bull. Environ. Contam. Toxicol., 78, 2007, 151-521.

[34]. E.R. Daka, and M. Moslen, Spatial and temporal variation of physicochemical parameters of sediment from Azuabie creek of the upper Bonny estuary, Niger Delta. Research Journal of Environmental and Earth Sciences, 5(4), 2013, 291-228.

[35]. M. Moslen and E.R. Daka, Attributes of the Subtidal Macrobenthos of Azuabie Creek in the upper Bonny Estuary, Niger Delta, Nigeria. Research Journal of Environmental and Earth Sciences 6(3), 2014. 143-155.

[36]. European Union, Setting maximum levels for certain contaminants in foodstuffs, Commission Regulation (EC) No 1881/2006; OJ L 364, 20.12.2006, p. 5

[37]. B. Staniskiene, P. Matusevicius, R. Budreckiene, and K.A. Skibniewska, Distribution of Heavy Metals in Tissues of Freshwater Fish in Lithuania; Polish J. of Environ. Stud., 15, 2006, 585-591.

[38]. H.A. Zaqoot, A.M Aish, N. Hisham, and H.N. Wafi, Baseline Concentration of Heavy Metals in Fish Collected from Gaza Fishing Harbor in the Mediterranean Sea along Gaza Coast, Palestine. Turkish Journal of Fisheries and Aquatic Sciences 17: 2017, 101109.

[39]. A. Abubakar, A. Uzairu, P.A. Ekwumemgbo, and O.J. Okunola, Risk Assessment of Heavy Metals in Imported Frozen Fish Scomber scombrus Species Sold in Nigeria: A Case Study in Zaria Metropolis. Advances in Toxicology Volume 2015, http://dx.doi.org/10.1155/2015/303245.

[40]. M. Malakootian, M.S. Mortazavi, and A. Ahmadi, Heavy metals bioaccumulation in fish of southern Iran and risk assessment of fish consumption. Environmental Health Engineering and Management Journal 3(2), 2016, 61-68.

[41]. S. Stoyanova, I. Sirakov, K. Velichkova, and Y. Staykov, Chemical composition and content of heavy metals in the flesh of the different marine fish species J. BioSci. Biotechnol. 2015, SE/ONLINE: 297-301.

[42]. H.M. Abdou, and M.A. Hassan Protective role of omega-3 polyunsaturated fatty acid against lead acetate-induced toxicity in liver and kidney of female rats. BioMed Res In,. 2014, doi:10.1155/2014/435857.

[43]. M. Harmanescu, L.M. Alda, D.M. Bordean, I. Gogoasa, and I. Gergen, Heavy metals health risk assessment for population via consumption of vegetables grown in old mining area; a case study: Banat County, Romania. Chem Central J 5: 2011, 64.

[44]. M Jovic, and S. Stankovic, Human exposure to trace metals and possible public health risks via consumption of mussels Mytilus galloprovincialis from the Adriatic coastal area, Food Chem Toxicol 70, 2014, 241-251.

[45]. Y. Tao, Z. Yuan, H. Xiaona, and M. Wei, Distribution and bioaccumulation of heavy metals in aquatic organisms of different trophic levels and potential health risk assessment from Taihu lake, China. Ecotoxicol Environ Saf, 81,2012, 55-64.

[46]. A. Taweel, M. Shuhaimi-Othman, A.K. Ahmad, Assessment of heavy metals in tilapia fish (Oreochromis niloticus) from the Langat River and Engineering Lake in Bangi, Malaysia, and evaluation of the health risk from tilapia consumption, Ecotoxicol Environ Saf 93, 2013, 45-51.

[47]. P.V. Krishna, K.M. Rao, I.V. Swaruparan, and D.S. Rao, Heavy metals concentration in fish Mugil cephalus from machilipatnam coast and possible health risks to fish consumers. British Biotechnology Journal 4(2), 2014, 126-35.

[48]. M.S. Islam, M.K. Ahmed, M.H. Al-Mamun, K.N. Islam, M. Ibrahim, and S. Masunaga) Arsenic and lead in foods: a potential threat to human health in Bangladesh. Food Add Contam Part A. doi:10.1080/19440049, 2014, 974686

[49]. G.V. Zodape, Metal contamination in commercially important prawns and shrimps species collected from Kolaba market of Mumbai (west coast) India. Int J Agri sci 4, 2014, 160-169.

[50]. NYSDOH (New York State Department of Health) Hopewell precision area contamination: appendix C-NYS DOH. Procedure for evaluating potential health risks for contaminants of concern, 2007, http://www.health.ny.gov/environmental/ investigations/hopewell/appendc.htm. 